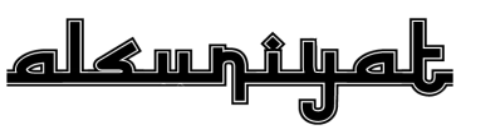

JURNAL PENELITIAN BAHASA, SASTRA, DAN

BUDAYA ARAB

P-ISSN: 2615-7241 | E-ISSN: 2721-480X // Vol. 2 No. 2 | 109-125

(1) https://ejournal.upi.edu/index.php/alsuniyat/index

\title{
PRAANGGAPAN DAN FUNGSI BAHASA PADA TUTURAN TOKOH DALAM FILM DZEEB KARYA NAJI ABU NOWAR
}

\author{
Lady Farah Aziza, Muna Nabila Amatullah \\ Universitas Islam Negeri Sunan Kalijaga Yogyakarta, Indonesia \\ E-mail: ladyfarahaziza16@gmail.com
}

\begin{abstract}
:
This study aims to determine the types of presuppositions and what language functions contained in the speech of characters in the film Dzeeb. Researchers used a descriptive analysis method using the method of referencing which has the basis of tapping techniques. Based on the results of research on the first Dzeeb film, the utterances of the characters have four presuppositions, namely existential, lexical, factive, and non-active presuppositions. Existential presuppositions become findings that dominate the utterances of the characters in the film. Counterfactual presuppositions and structural presuppositions are not found in the speech of the characters in the Dzeeb film. The second is the function of language in speech utterances there are language functions including fatigue, directive, metalinguistic, and imaginative, referential functions. The directive language function is the finding that dominates the utterances of the characters in the Dzeeb film.
\end{abstract}

Keywords:

Pragmatics; Presupposition; Language function

\begin{abstract}
Abstrak
Penelitian ini bertujuan untuk mengetahui jenis praanggapan serta fungsi bahasa apa saja yang terdapat pada tuturan tokoh dalam film Dzeeb. Peneliti menggunakan metode deskriptif analisis dengan menggunakan metode simak yang memiliki dasar berupa teknik sadap. Berdasarkan hasil penelitian pada film Dzeeb pertama tuturantuturan tokoh memiliki empat praanggapan, yaitu praanggapan eksistensial, leksikal, faktif, dan non-faktif. Praanggapan eksistensial menjadi temuan yang mendominasi tuturan tokoh dalam film tersebut. Praanggapan konterfaktual dan praanggapan struktural tidak ditemukan pada tuturan tokoh dalam film Dzeeb. Adapun yang kedua yaitu fungsi bahasa pada tuturan-tuturan tokoh terdapat fungsi bahasa di antaranya fungsi fatik, direktif, metalinguistik, dan imajinatif, referensial. Fungsi bahasa direktif menjadi temuan yang paling mendominasi tuturan tokoh dalam film Dzeeb.

Kata Kunci:

Pragmatik; Praanggapan; Fungsi bahasa
\end{abstract}

\section{PENDAHULUAN}

Dalam memaknai wacana atau suatu gagasan kita tidak hanya terpaku pada tuturan yang disampaikan, namun juga konteks yang mengikuti dan bagaimana pengaruhnya. Terkadang maknanya menjadi sulit diterka karena pemahaman makna tersebut tidak hanya berasal dari dalam tuturan tetapi juga dari luar tuturan. Begitu pula ketika memaknai film, pemahaman kita terhadap isi film tidak hanya mengacu pada film yang sedang kita tonton tetapi juga mengaitkannya dengan pengetahuan di luar film tersebut (Yule, 2006). Pengetahuan tersebut dapat membantu kita memahami film secara umum lebih dalam terhadap pesan yang ingin disampaikan oleh pembuat film tersebut. 
Pemaknaan film dapat terjadi ketika tuturan yang disampaikan oleh partisipan penutur dipahami oleh penonton serta adanya pengetahuan bersama dan konteks situasi yang terjadi dalam tuturan. Anggapan tersebut terbentuk ketika penonton menonton awal film, berada di tengah-tengah film, sampai akhirnya penonton mengetahui akhir cerita dalam film tersebut. Banyak media yang mencoba mengarahkan pemahaman calon penonton mengenai film yang yang akan ditontonya melalui resensi film di majalah atau televisi.

Kesinambungan antar teks film, dalam hal ini dialog, dan juga adegan yang memvisualisasikan pesan menjadi penting ketika film itu sudah dipahami dengan melenceng oleh penontonnya. Ketika praanggapan terbentuk dibenak penonton saat menonton awal suatu adegan, penonton memiliki asumsi awal yang kemungkinan berbeda dengan asumsi berikutnya. Saat mengaitkan cerita lengkap antara tuturan dengan visualisasi serta peran pemainnya, keutuhan dari sisi adegan tersebut menjadi tercapai dan koheren dengan adegan berikut. Adegan dalam film merupakan bagian-bagian yang saling berkaitan dan akhirnya membentuk keutuhan film.

Selain itu, adegan dan dialog yang tercipta tidak sesuai dan menimbulkan adanya "kekosongan" antar adegan bisa membuat pesan yang disampaikan menjadi tidak jelas. Hal ini terkadang tidak menjadi "masalah" ketika seorang pembuat film membuat film dengan idealisme atau unsur seni yang lebih ditonjolkan. Pembuat film tersebut tidak memaksa penonton untuk memaknai film dengan akhir yang eksplisit atau sesuai dengan keinginan pembuatnya. Pembuat film lebih banyak membebaskan penontonnya untuk berimajinasi dengan pikirannya.

Film Dzeeb yang dibahas dalam penelitian ini merupakan film di dalamnya terdapat filosofi tanah Arab yang terkandung rasa persaudaraan, revolusi Arab, hingga proses pendewasaan seorang Dzeeb. Dzeeb adalah nama seorang anak dari Bani Bedouin yang diperankan oleh Jacir Eid Al-Hwietat. Dzeeb berasal dari bahasa Arab ذيب yang berarti serigala. Adegan yang dibangun melalui tuturan partisipannya dan konteks situasi yang terjadi serta pengetahuan bersama yang melatari tentu menimbulkan banyak pemahaman dan praanggapan.

Praanggapan adalah bagian dari pragmatik yang mengaitkan dua proposisi sehingga dapat dipahami maknanya. Praanggapan didapatkan dari pernyataan yang disampaikan tanpa perlu ditentukan apakah praanggapan tersebut benar atau salah, yang mengacu pada pernyataan sebenarnya. Pemahaman mengenai praanggapan ini melibatkan dua partisipan 
utama, yaitu dua penutur atau yang membuat suatu pernyataan atau tuturan dan mitra tutur dan bisa diasosiasikan dengan pemilihan kata atau diksi, frase, dan struktur (Yule, 2006).

Dalam kajian wacana yang melihat sebuah gagasan dalam tuturan dilihat melalui kohesi dan koheresinya. Pragmatik melihat tuturan secara lengkap beserta konteks situasinya. Praanggapan juga didefinisikan sebagai suatu hal yang dipercaya secara latar belakang, kaitannya dengan tuturan yang dimiliki dan diketahui oleh penutur dan mitra tutur sebagai tuturan yang sesuai dengan konteks (Levinson, 1983:179).

Peneliti mencoba mengambil sampel data dari dialog-dialog film Dzeeb untuk praanggapan:

Pada video durasi ke 18.46-18.48

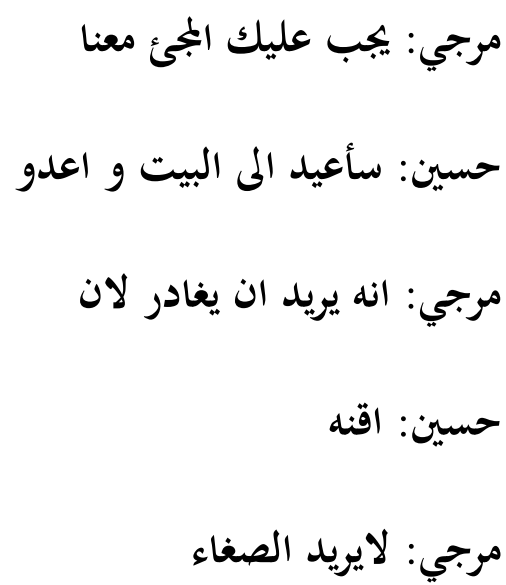

Secara konteks, data ini disampaikan oleh dua partisipan yang sedang berbicara yaitu Marji dan Hussein di gurun pasir pada siang hari, di sekeliling dua partisipan tersebut terdapat Dzeeb dan orang asing. Tuturan yang disampaikan dalam bentuk dialog ini mengemukakan apa yang diminta oleh Marji kepada Hussein. Marji meminta Hussein untuk menjadi pemandu dalam perjalannya bersama orang asing. Pada saat itu Hussein segera menghampiri unta untuk menghampiri unta.

Tuturan di atas mengandung praanggapan 'Hussein bersiap-siap melanjutkan perjalanan'. Mengacu pada kalimat dalam tuturan yang disampaikan Marji kepada Hussein " يجب عليك المجئ معنا", yang merupakan perintah yang disampaikan pada Hussein, Hussein tidak langsung menjawab dengan "ya" atau "tidak" tetapi langsung menghampiri unta untuk segera melanjutkan perjalanan. Hal ini menunjukkan praanggapan leksikal, karena tanpa adanya jawaban yang disampaikan melalui tuturan, Hussein menuruti dengan tindakan yang dipahami sebagai jawaban “ya” oleh Marji. 
Pemahaman atas tuturan hingga muncul praanggapan leksikal karena kedua partisipan memiliki pengetahuan bersama ketika menyampaikan tuturan tersebut. Keduanya memiliki pengetahuan bersama bahwa orang asing yang meminta Hussein memandu jalan ingin segera melanjutkan perjalanannya. Keduanya juga sudah paham akan konteks situasi, ketika Marji memerintahkan kepada Hussein untuk memandu jalan Hussein langsung merespon sekaligus tanda bahwa Hussein sudah siap untuk melanjutkan perjalanan. Tuturan di atas termasuk kedalam jenis praanggapan leksikal, praanggapan leksikal merupakan praanggapan yang dalam pemakaian suatu bentuk dengan makna yang dinyatakan secara konvensional ditafsirkan dengan praanggapan lain (yang tidak dinyatakan) dipahami.

Berdasarkan hal tersebut, peneliti ingin mengetahui lebih lanjut bentuk dari praanggapan yang terjadi dalam dialog film Dzeeb, dilihat dari sisi pragmatik. Penelitian ini dirasa sangat diperlukan untuk mengetahui maksud atau tujuan dari konteks yang kadang belum tentu sampai pada penikmat karya tersebut, khususnya dalam film berbahasa.

\section{METODE}

Penelitian yang digunakan adalah analisis deskriptif. Sebagaimana pada umumnya, bahwa analisis deskriptif ini merupakan sebuah metode yang digunakan untuk menemukan dan mengungkapkan permasalah sistematis, dengan cara mendeskripsikan data-data disusul dengan analisis. Dalam penelitian ini, peneliti akan mendeskripsikan kalimat-kalimat berupa tuturan antar tokoh yang mengandung praangapan dan fungsi bahasa pada subtitle dalam film Dzeeb.

Peneliti menjadikan film Dzeeb sebagai objek dari penelitian. Hal ini dikarenakan masih banyak para penikmat karya sastra asing yang tidak mengerti secara keseluruhan makna yang terdapat dalam film tersebut, baik secara teks maupun konteks. Sumber data penelitian ini adalah kata dan kalimat yang terdapat pada subtitle film Dzeeb yang mengandung praanggapan serta fungsi bahasa juga konteks-konteks yang menyertainya.

Adapun metode yang digunakan dalam pengumpulan data, yakni metode simak. Di mana peneliti menyimak penggunaan bahasa yang terjadi dalam film Dzeeb. Mahsun (2014:92) mengatakan bahwa menyimak tidak hanya berkaitan dengan penggunaan secara lisan, tetapi juga penggunaan bahasa secara tertulis. Metode ini memiliki beberapa teknik di antaranya; teknik rekam dan teknik catat.

Seperti yang telah dijelaskan sebelumnya bahwa data dari penelitian ini berupa kalimat

yang terdapa pada subtitle dalam film, berikut tahapan yang peneliti lakukan untuk 
mendapatkan data; (1) menonton seluruh video film Dzeeb secara cermat; (2) menyimak subtitle dalam film yang merupakan praanggapan; (3) mencatat data yang merupakan praanggapan dan fungsi bahasa yang terdapat pada subtitle dalam film Dzeeb; (4) menganalisis hasil data yang telah ditemukan, sesuai dengan teori yang ada dalam pragmatik; (5) kemudian peneliti mencari referensi sebagai alat bantu untuk melakukan sintesis awal lalu membuat simpulan yang dapat menjawab pertanyaan yang telah dirumuskan.

Bagian penting dari penelitian ini adalah setelah data didapatkan kemudian dikelompokkan berdasarkan jenisnya masing-masing lalu dianalisis menggunakan metode padan. Metode ini merupakan metode yang menggunakan unsur di luar bahasa sebagai alat bantu analisis. Alat-alat unsur penentu di luar bahasa yang dimaksud adalah konteks tuturan dan lawan tutur.

\section{HASIL DAN PEMBAHASAN}

Sebagaimana telah diketahui bahwa penelitian ini menggunakan film sebagai objek dan data berupa kata atau kalimat dari subtitle yang terdapat dalam film. Sehingga peneliti akan berhadapan dengan film Dzeeb untuk menyimak dialog secara seksama.

\section{Klasifikasi Praanggapan}

Jenis-jenis praanggapan seperti yang telah diungkapkan oleh Yule (2006) yaitu: 1) praanggapan eksistensial, 2) praanggapan faktif, 3) pranggapan non-aktif, 4) praanggapan leksikal, 5) pranggapan structural, dan 6) pranggapan konterfaktual.

\section{a. Praanggapan Eksistensial}

Praanggapan eksistensial merupakan praanggapan yang mengasosiasikan adanya suatu keberadaan. Jenis praanggapan ini tidak hanya diasumsikan keberadaannya dalam kalimat-kalimat yang menunjukkan kepemilikan, tetapi lebih luas lagi keberadaan atau eksistensi dari pernyataan tuturan tersebut. Praanggapan eksistensial menunjukkan bagaimana keberadaan atas suatu hal dapat disampaikan lewat praanggapan. Pada dialog dalam film Dzeeb yang diuraikan dengan bentuk subtitle ditemukan praanggapan eksistensial sebagai berikut:

\section{Data 1}

Pada video durasi ke 00:18:47

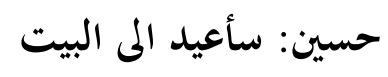


Hussein: saya akan kembali ke rumah.

Analisis konteks: kata 'البيت pada tuturan sebagai objek tempat. 'البيت' dalam konteks merupakan bangunan untuk tempat tinggal namun bukan terbuat dari material kokoh melainkan bangunan yang terbuat dari terpal yang umumnya disebut dengan tenda yang bersifat tidak permanen seperti yang terihat bahwa tempat yang dipijak oleh penutur di hamparan gurun, terdapat kemungkinan kecil untuk memiliki tempat tinggal yang terbuat dari bahan material kokoh.

Penutur dan mitra tutur memiliki pengetahuan bersama bahwa yang dimaksud 'البيت 'البيت' adalah sebuah tenda yang dijadikan sebagai tempat tinggal Hussein. Kata mempraanggapkan bahwa "rumah ada". Kata 'البيت mengindikasikan adanya sebuah rumah yang dituturkan oleh Hussein. Hussein menggunakan kata ' البيت untuk menjadi objek dari tujuannya dan rumah tersebut memang ada.

\section{Data 2}

Pada video durasi ke 00: 37:28

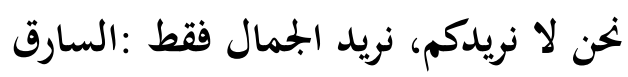

Perampok: Kami tidak menginginkan kalian, kami hanya menginginkan untanya.

Analisis konteks: kata 'لحن لا نريدكم، نريد الجمال فقط" dalam tuturan perampok" mempraanggapkan "unta ada". Penutur dan mitra tutur memiliki pengetahuan bersama bahwa yang diinginkan oleh perampok adalah unta yang ditunggangi oleh orang Inggris.

\section{Data 7}

Pada video durasi ke 00: 24: 05

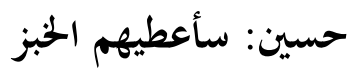

Hussein: aku akan memberi mereka roti.

Analisis konteks: kata 'الخبز' dalam tuturan mengindikasikan adanya keberadaan roti sebagai sesuatu yang akan diberikan oleh Hussein kepada Marji dan orang Inggris. ketika Hussein menuturkan tuturan tersebut, mengisyaratkan bahwa roti benar-benar ada, karna pada saat bertutur demikian pun Hussein sedang memegang roti.

\section{Data 8}

Pada video durasi ke 00: 26: 54

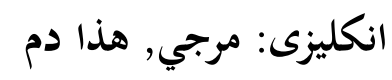


ALSUNIYAT: Jurnal Penelitian Bahasa, Sastra, dan Budaya Arab

Orang Inggris: Marji, ini darah.

Analisis konteks: kata 'مرجي' dalam tuturan mempraanggapkan "Marji ada”. Kata 'dalam tuturan mengindikasikan adanya keberadaan seseorang sebagai seseorang yang diberi informasi oleh orang Inggris ketika ada sesuatu yang mengejutkan.

\section{b. Praanggapan Faktif}

Praanggapan faktif merupakan praanggapan yang mengikuti kata kerja yang dapat dianggap sebagai suatu kenyataan. Menurut Yule (2006) praanggapan ini juga muncul dari informasi yang ingin disampaikan dinyatakan dengan kata-kata yang menunjukkan suatu fakta atau berita yang diyakini kebenarannya. Kata-kata yang bisa menyatakan fakta dalam tuturan adalah kata kerja yang memberikan makna pasti dalam tuturan tersebut. Pada dialog dalam film Dzeeb yang diuraikan dengan bentuk subtitle ditemukan praanggapan faktif sebagai berikut:

\section{Data 4}

\section{Pada video durasi ke 01:15:31}

$$
\text { الذي يذهب لا يعود :السارق }
$$

Perampok: yang pergi tidak akan kembali.

Analisis konteks: kata kerja 'ذَب pada tuturan “'الذي يذهب لا يعود" mempraanggapakan “meninggalkan suatu tempat sebelumnya (dunia)”. Kata kerja 'ذَب digunakan perampok untuk mempraanggapakan bahwa ada suatu kejadian yang merupakan suatu kenyataan, karena pada saat perampok menuturkan kalimat "الذي يذهب لا يعود", perampok melihat Hussein telah tiada.

\section{Data 5}

Pada video durasi ke 01:18: 42

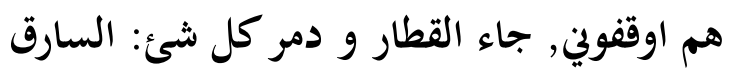

Perampok: Mereka menghentikan saya, datangya kereta menghancurkan segalanya.

Analisis konteks: kata 'وقف' dalam tuturan pada data 5, juga memunculkan praanggapan lain. Pada kalimat "هم اوقفوني ' "هم ' adalah sebab juga sebagai pelaku dari kata kerja 'وقف', yang mempraanggapakan bahwa "perampok berhenti karena terpaksa sebab ada unsur yang menghentikannya". Dari tuturan perampok muncul praanggapan 
bahwa ia berhenti bukan karna kemauannya sendiri melainkan karna ada unsur yang membuatnya tidak lagi melakukan aktivitasnya dalam memandu haji.

Praanggapan di atas mencandrakan bahwa perampok kemungkinan mempunyai keinginan yang lain, yaitu tetap menjadi pemandu haji, tetapi tidak bisa dilakukan karena جاء القطار " kereta lebih banyak digunakan untuk pergi haji. Hal tersebut dipicu dari kalimat " yang mengikutinya.

\section{Data 10}

\section{Pada video durasi ke 01:04:59}

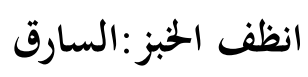

Perampok: bersihkan roti.

Analisis konteks: pada tuturan “'انظف الخبز” terdapat kata 'انظف' mempraanggapkan bahwa "roti kotor". Praanggapan menggambarkan bahwa pada roti terdapat suatu hal yang menyebabkan roti kotor.

\section{c. Praanggapan Non-aktif}

Praanggapan non-faktif adalah suatu presupposisi yang diasumsikan tidak benar. Menurut Dia (2012:23) praanggapan ini juga dianggap sebagai praanggapan yang masih memungkinkan adanya pemahaman yang salah karena penggunaan kata-kata yang tidak pasti dan masih ambigu. Pada dialog dalam film Dzeeb yang diuraikan dengan bentuk subtitle ditemukan praanggapan faktif sebagai berikut:

\section{Data 3}

\section{Pada video durasi ke 00:39:15}

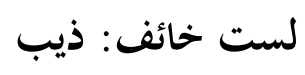

Dzeeb: aku bukan penakut.

Analisis konteks: tuturan " لست خائف" mempraanggapkan bahwa "berharap tidak

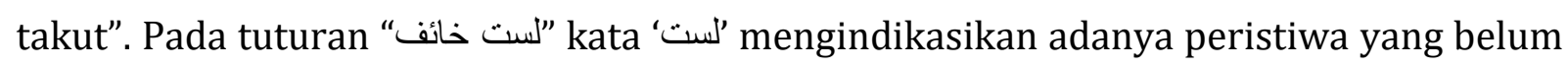
dilakukan (masih angan-angan).

\section{d. Praanggapan Leksikal}

Praanggapan leksikal merupakan praanggapan yang dalam pemakaian suatu bentuk dengan makna yang dinyatakan secara konvensional ditafsirkan dengan praanggapan lain (yang tidak dinyatakan) dipahami. Yule menjelaskan (2006) dalam kasus praanggapan leksikal, pemakaian ungkapan khusus oleh penutur diambil untuk 
ALSUNIYAT: Jurnal Penelitian Bahasa, Sastra, dan Budaya Arab

mempraanggapkan sebuah konsep lain (tidak dinyatakan), sedangkan pada kasus praanggapan faktif, pemakaian ungkapan khusus diambil untuk mempraanggapkan kebenaran informasi yang dinyatakan setelah itu. Pada dialog dalam film Dzeeb yang diuraikan dengan bentuk subtitle ditemukan praanggapan faktif sebagai berikut:

\section{Data 6}

Pada video durasi ke 00:24:59

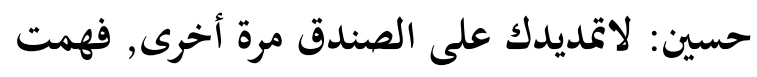

Hussein: jangan membentangkan tangan lagi pada kotaknya, mengerti.

Analisis konteks: kata penggunaan kata keterangan 'مرة أخرى memicu praanggapan bahwa "sebelumnya Dzeeb pernah menyentuh kotak itu". Secara leksikal, kata 'مرة اخرى mempunyai arti bahwa hal itu dilakukan untuk kesekian kali. Maka, tidaklah mengherankan bahwa tuturan tersebut diasumsikan bahwa Dzeeb melakukan perbuatan menyentuh kotak tersebut.

\section{Data 9}

Pada durasi video ke 00: 05: 20

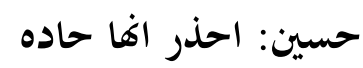

Hussein: berhati-hatilah sesungguhnya itu tajam.

Analisis konteks: kata 'حاد' dalam tuturan Hussein mempraanggapkan bahwa "belati bisa melukai”. Kata 'حاد' mengindikasikan sifat fisik dari belati. Pada saat itu Dzeeb memegang belati tersebut dengan bercanda.

Untuk jenis praanggapan struktural dan konterfaktural peneliti tidak menemukan adanya data yang sesuai dalam penelitian ini.

\section{Klasifikasi Fungsi Bahasa}

Bagi sosiolinguistik konsep bahwa bahasa adalah alat atau berfungsi untuk menyampaikan pikiran dianggap terlalu sempit, sebab seperti dikemukakan Fishman (1972) bahwa yang menjadi persoalan sosiolinguistik adalah "who speak what language to whom, when and to what end". Oleh karena itu, fungsi-fungsi bahasa itu, antara lain dapat dilihat dari sudut penutur, pendengar, kode, dan amanat pembicaraan.

\section{a. Fungsi Direktif}


Menurut Lubis (2015:4), fungsi direktif memungkinkan kita untuk mengajukan permintaan, saran, membujuk, meyakinkan, dan sebagainya. Di sini fungsi bahasa itu tidak "hanya membuat si pendengar melakukan sesuatu", tetapi melakukan kegiatan yang sesuai dengan yang dimaui si pembicara. Hal ini dapat dilakukan si penutur dengan menggunakan kalimat-kalimat yang menyatakan perintah, himbauan permintaan, maupun rayuan. Pada dialog dalam film Dzeeb yang diuraikan dengan bentuk subtitle ditemukan fungsi bahasa direktif sebagai berikut:

\section{Data 2}

\section{Pada video durasi ke 00:11:31}

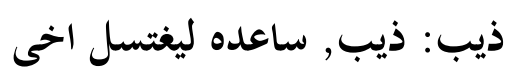

Kakak Dzeeb: Dzeeb, bantu dia untuk mencuci

Analisis konteks: tuturan "ذيب, ساعده ليغتسل" bila dilihat dari segi kontak antara penutur atau lawan bicara, maka bahasa itu berfungsi direktif. Fungsi direktif merupakan fungsi yang mengatur tingkah laku pendengar.

\section{Data 4}

\section{Pada video durasi ke 01: 06: 42}

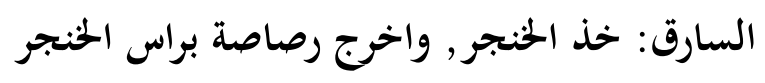

Perampok: ambil belatinya, dan keluarkan pelurunya dengan ujung belati.

Analisis konteks: Tuturan pada data ini disampaikan oleh perampok kepada Dzeeb. Kaki perampok terluka akibat terkena tembakan dan di kakinya terdapat peluru yang bersarang. Perampok pun memerintahkan Dzeeb untuk membantunya mengeluarkan peluru yang ada dikakinya.

Pada kalimat “خذ الخنجر' kata 'خذ' sebagai pemicu bahwa perampok memerintah Dzeeb. Kata 'خذ' adalah kata perintah atau dalam bahasa fi'il amr. Kata 'خذ' memiliki asal kata ‘ خذ 'خ 'merupakan fi'il bina mahmuz (mahmuz fa' karena fa' fi'ilnya berupa huruf alif).

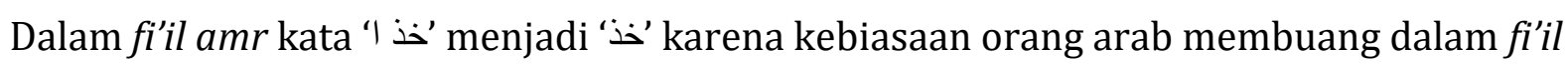
bina mahmuz yang dijadikan fi'il amr. Setelah mendengar tuturan perampok Dzeeb mengikuti apa yang diminta perampok. Dzeeb mengambil belati yang diberi oleh perampok.

\section{Data 5}

Pada video durasi ke 01:07:48 
ALSUNIYAT: Jurnal Penelitian Bahasa, Sastra, dan Budaya Arab

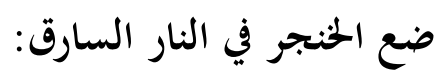

Perampok: letakkan belatinya di api.

Analisis konteks: Tuturan pada data ini disampaikan oleh perampok kepada Dzeeb. Setelah Dzeeb mengeluarkan peluru dari kaki perampok. Perampok meminta kepada Dzeeb untuk meletakkan belati yang digunakan untuk mengeluarkan peluru di api. Pada

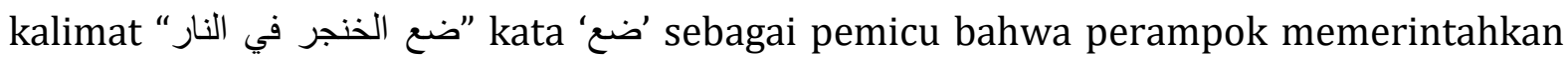
Dzeeb. Kata 'ضع 'ضع ' merupakan fi'il amr yang asal katanya adalah ' Dzeeb melakukan apa yang dikatakatan perampok. Dzeeb segera membawa belati kearah abu sisa api unggun yang masih terdapat api dan meletakkan belati di atas api. Tuturan pada data ini dilihat dari segi kontak antara penutur atau lawan bicara, maka bahasa itu berfungsi direktif.

\section{Data 7}

\section{Pada video durasi ke 01:04:59}

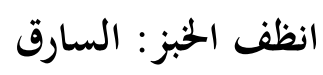

\section{Perampok: bersihkan roti.}

Analisis konteks: Tuturan pada data 7 disampaikan oleh perampok kepada Dzeeb. Perampok baru bangun dari tidurnya dan langsung mengusik abu yang bercampur dengan tongkat untuk mengambil roti yang tertutup oleh abu. Melihat Dzeeb masih tertidur dan perampok pun membangunkan Dzeeb, Kemudian perampok memerintahkan Dzeeb untuk membersihkan roti yang kotor karena tertutup abu dan pasir agar roti tersbut bisa bersih dan layak untuk dimakan. Tuturan pada data 7 bila dilihat dari segi kontak antara penutur atau lawan bicara, maka bahasa itu berfungsi direktif. Fungsi direktif merupakan fungsi yang mengatur tingkah laku pendengar.

\section{b. Fungsi Fatik}

Bila dilihat dari segi kontak antara penutur dan pendengar maka bahasa di sini berfungsi fatik, Jacobson (1960), Finnochiaro (1974) meyebutnya interpersonal, dan Halliday (1973) menyebutnya interactional), yaitu fungsi menjalin hubungan, memelihara, memperihatkan perasaan bersahabat, atau solidaritas sosial. Ungkapanungkapan yang digunakan biasanya sudah berpola tetap, seperti pada waktu berjumpa, pamit, membicarakan cuaca, atau menanyakan keadaan keluarga. 
Oleh karena itu, ungkapan-ungkapannya tidak dapat diartikan atau diterjemahkan secara harfiah. Ungkapan-ungkapan fatik ini biasanya juga disertai dengan unsur paralinguistik, seperti senyuman, gelengan kepala, serak-gerik tangan, air muka, dan kedipan mata. Ungkapan-ungkapan tersebut yang disertai unsur paralinguistik tidak mempunyai arti, dalam arti memberikan informasi, tetapi membangun kontak sosial antara para partisipan di dalam petuturan itu. Pada dialog dalam film Dzeeb yang diuraikan dengan bentuk subtitle ditemukan fungsi bahasa fatik sebagai berikut:

\section{Data 1}

\section{Pada video durasi ke 00:08:04}

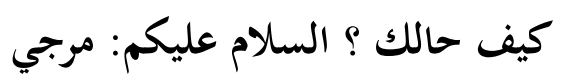

\section{Marji: Assalamualaikum.apa kabar?}

Analisis konteks: Tuturan yang disampaikan oleh Marji disampaikan kepada kakak Dzeeb sebagai bentuk pertanyaan mengenai kabar kakak Dzeeb. Pada saat itu Marji mendatangi tempat tinggal Dzeeb. Dan tuturan tersebut terjadi ketika Marji bertemu dengan kakak Dzeeb dan orang-orang yang ada di tempat tinggal Dzeeb. Tuturan tersebut merupakan ungkapan yang berpola tetap. Tuturan " السلام عليكم . كيف حالك ؟ bila dilihat dari segi kontak antara penutur dan pendengar maka bahasa di sini berfungsi fatik. Fungsi fatik yaitu fungsi menjalin hubungan, memelihara, memperlihatkan perasaan bersahabat, atau solidaritas sosial.

\section{Data 8}

Pada video durasi ke 00: 15:59

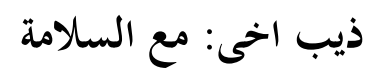

Kakak tetua Dzeeb: keselamatan menyertaimu.

Analisis konteks: Tuturan "مع السلامة" bila dilihat dari segi kontak antara penutur dan pendengar maka bahasa di sini berfungsi fatik. Fungsi fatik yaitu fungsi menjalin hubungan, memelihara, memperlihatkan perasaan bersahabat, atau solidaritas sosial. Ungkapan yang digunakan biasanya sudah berpola tetap. Ungkapan fatik biasanya disertai dengan unsur paralinguistik, seperti senyuman, gelengan kepala, gerak-gerik tangan dan lain sebagainya. Ungkapan tersebut yang disertai dengan unsur paralinguistik tidak mempunyai arti, dalam ari memberikan informasi, tetapi untuk membangun kontak sosial antara penutur dan para partisipan di dalam pertuturan itu. 


\section{c. Fungsi Referesial}

Fungsi referensial menurut Lubis (2015:4) adalah yang berhubungan dengan kemampuan untuk menulis atau berbicara tentang lingkungan kita yang terdekat dan juga mengenai bahasa itu sendiri.

Di sini bahasa itu berfungsi sebagai alat untuk membicarakan objek atau peristiwa yang ada di sekeliling penutur atau yang ada dalam budaya pada umumnya. Fungsi referensial inilah yang melahirkan paham tradisional bahwa bahasa itu adalah alat untuk menyatakan pikiran, untuk menyatakan bagaimana pendapat si penutur tentang dunia di sekelilingnya. Pada dialog dalam film Dzeeb yang diuraikan dengan bentuk subtitle ditemukan fungsi bahasa referensial sebagai berikut:

\section{Data 10}

Pada video durasi ke 01:15:15

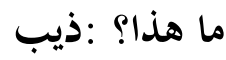

Dzeeb: apa itu?

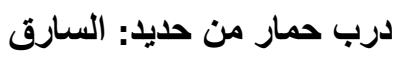

\section{Perampok: jalan keledai dari besi}

Analisis konteks: Dialog data ini merupakan dialog yang membicarakan objek yang ada disekeliling penutur bila dilihat dari segi topik ujaran, maka bahasa pada dialog berfungsi referensial. Fungsi referensial merupakan paham tradisional bahwa bahasa itu adalah alat untuk menyatakan pikiran, untuk menyatakan bagaimana pendapat penutur tentang dunia disekelilingnya.

\section{d. Fungsi Metalingual}

Kalau dilihat dari segi kode yang digunakan, maka bahasa itu berfungsi metalingual atau metalinguistik (Jacobson, 1960, Finnochiaro, 1974) yakni bahasa itu digunakan untuk membicarakan bahasa itu sendiri. Memang tampaknya agak aneh, biasanya bahasa itu digunakan untuk membicarakan masalah lain, seperti masalah politik, ekonomi atau pertanian. Tetapi dalam fungsinya di sini bahasa itu digunakan untuk membicarakan atau menjelaskan bahasa.

Hal ini dapat dilihat dalam proses pembelajaran bahasa di mana kaidah-kaidah atau aturan-aturan bahasa dijelaskan dengan bahasa. Juga dalam kamus monolingual, 
bahasa itu digunakan untuk menjelaskan fungsi bahasa (dalam hal ini kata) itu sendiri. Pada dialog dalam film Dzeeb yang diuraikan dengan bentuk subtitle ditemukan fungsi bahasa metalingual sebagai berikut:

\section{Data 9}

Pada video durasi ke 00:10: $r \cdot-00: 18: 48$

Orang Inggris: kita butuh kakanya sebagai pemandu

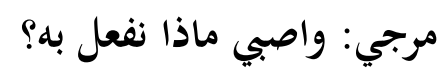

Marji: apa yang kita lakukan kepada anak itu?

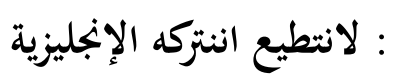

Orang Inggris: kita tidak bisa meninggalkannya

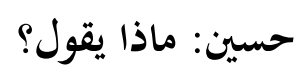

Hussein: apa yang dia katakan?

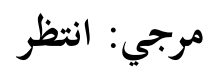

Marji: sebentar

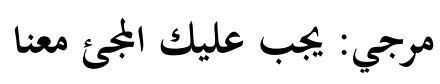

Marji: kau harus ikut dengan kami.

Analisis konteks: Percakapan di atas memiliki fungsi bahasa metalinguistik. fungsi bahasa metalinguistik merupakan bahasa digunakan untuk menjelaskan bahasa itu sendiri. Hal ini dapat dilihat dalam tuturan yang disampaikan oleh Marji kepada Hussein adalah bahasa Arab untuk menjelaskan bahasa Inggris yang tidak dipahami oleh Hussein. Namun meskipun memiliki perbedaan antara bahasa Arab dan bahasa Inggris namun tidak menghilangkan maksud dari tuturan awal (bahasa Inggris).

\section{e. Fungsi Imaginatif}

Kalau dilihat dari segi amanat (message) yang akan disampaikan maka bahasa itu berfungsi imaginatif (Halliday, 1973, Finnochiaro, 1974). Sedangkan Jacobson (1960) menyebutnya fungsi poetic speech). Sesungguhnya, bahasa itu dapat digunakan untuk menyampaikan pikiran, gagasan, dan perasaan; baik yang sebenarnya, maupun yang hanya imajinasi (khayalan/rekaan) saja. Fungsi imaginative ini biasanya berupa karya 
ALSUNIYAT: Jurnal Penelitian Bahasa, Sastra, dan Budaya Arab

seni (puisi, cerita, dongeng, lelucon) yang digunakan untuk kesenangan penutur, maupun para pendengarnya. Sadnoto menambahkan (dalam Lubis 2015:4) fungsi imajinatif adalah kemampuan untuk dapat menyusun irama, sajak, cerita tertulis maupun lisan. Fungsi ini sukar diajarkan, kecuali kalau siswanya berbakat untuk hal itu-hal semacam itu. Pada dialog dalam film Dzeeb yang diuraikan dengan bentuk subtitle ditemukan fungsi bahasa imaginatif sebagai berikut:

\section{Data 3}

Pada video durasi ke 01: 11:18

$$
\text { يا ذيب :السارق }
$$

Perampok: wahai srigala

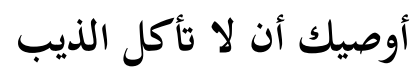

Kumohon jangan makan srigala

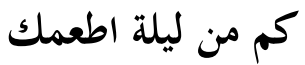

Berapa malam ia memberimu makan

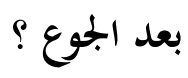

Saat kau kelaparan

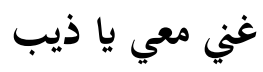

Saat kau kelaparan

Analisis konteks: Tuturan pada data 3 disampaikan oleh perampok kepada Dzeeb. Sebelum tuturan ini disampaikan perampok bertanya pada Dzeeb "siapa namamu?" Dzeeb pun menjawab "Dzeeb". Tidak lama setelah itu perampok mulai merebahkan tubuhnya dan merangkai kalimat yang kemudian dituturkan dengan irama. Tuturan pada dat a ini juga merupakan tuturan dalam bentuk puisi.

\section{Data 6}

Pada video durasi ke 01: 17: 48

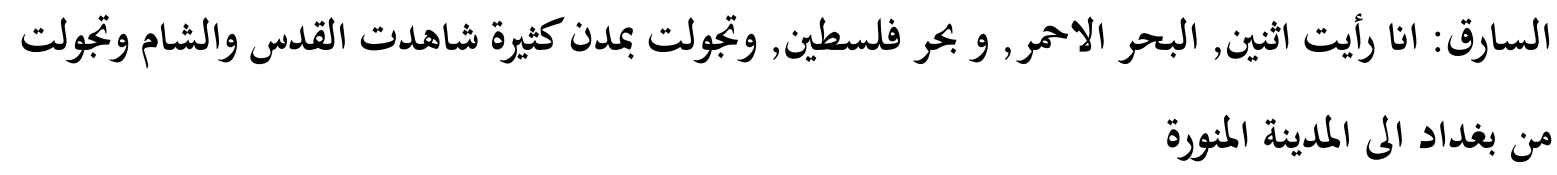


Perampok: Aku melihatnya dua kali, laut merah, dan laut palestina, dan berkeliling kota banyak, aku melihat Yerusalem dan Levant, Dan mengembara dari Baghdad ke Madinah.

Analisis konteks: Tuturan pada data 6 disampaikan oleh perampok kepada Dzeeb. Saat itu Dzeeb sedang duduk dan perampok berbaring, mereka berada diantara api unggun, saling berbicara. Perampok menceritakan apa yang pernah dialaminya kepada Dzeeb. ia menceritakan bahwa ia pernah melihat laut. Tuturan yang disampaikan oleh perampok memiliki fungsi bahasa imaginatif. Fungsi imaginatif merupakan yang digunakan untuk menyampaikan pikiran, gagasan, dan perasaan. Baik yang sebenarnya maupun yang hanya imajinasi saja.

Untuk jenis fungsi bahasa personal atau pribadi pada dialog dalam film Dzeeb yang diuraikan dengan bentuk subtitle peneliti tidak menemukan adanya data yang sesuai dengan jenis fungsi ini.

\section{SIMPULAN}

Berdasarkan hasil penelitian dan pembahasan yang telah diuraikan, maka dapat disimpulkan bahwa dalam dialog film Dzeeb karya Naji Abu Nowar terdapat 20 data dengan masing-masing 10 data untuk klasifikasi praanggapan dan fungsi bahasa. Untuk klasifikasi praanggapan eksistensial terdapat empat data, praanggapan faktif ada tiga data, praanggapan non-aktif ada satu data, dan praanggapan leksikal ada dua data. Dari klasifikasi fungsi bahasa fatik dua data, fungsi bahasa direktif empat data, fungsi bahasa metalingual satu data, fungsi bahasa referensial satu data, dan fungsi bahasa imaginatif dua data.

\section{DAFTAR PUSTAKA}

Dia, Eva Eri. (2012). Analisis praanggapan: Konsep Tindak Tutur (Presupposition) dalam Program Talkshow. Malang: Madani.

Finocchiaro, Mary. (1974). English as a Second Language: from Theory to Practice, (New York:

Regents Publishing Company) 47 Praninkas, J. Rapid Review of English Grammar. (2nd Ed).

New Delhi: PrenticeHall of India Private Limited.

Halliday, Michael. (1973). Explorations in the Functions of Language. London: Edward Arnold. Jacobson, Roman. (1960). Closing Statements: Linguistics and Poetics. T.A Sebeok ed. Style in Language. E-Resource. New york: MIT Press.

Levinson, C. Stephen. (1983). Pragmatics. Cambridge University Press. 
ALSUNIYAT: Jurnal Penelitian Bahasa, Sastra, dan Budaya Arab

Lubis, Hamid Hasan. (2015). Analisis Wacana Pragmatik. Bandung: Angkasa.

Mahsun. (2014). Metode Penelitian Bahasa: Tahapan Strategi, Metode, dan Tekniknya. Depok: Rajawali Pers.

Yule, George. (2006). Pragmatik. Yogyakarta: Pustaka Pelajar 